\title{
Anti-Violence Education Against Children
}

\author{
Yuyun Yulianingsih
}

Received: 20052016 / Accepted: 25052016 / Published online: 13122016

๑) 2016 Association of Indonesian Islamic Kindergarten Teachers Education Study Program

\begin{abstract}
This article aimed to analyze the anti-violence education to early childhood in Islamic perspective. Documentation is used as data collection method in this research. And critical analysis is used as data analysis technique. By this method, the research finds that: (1) violence against children occurs because of lack of understanding about what is exactly the characteristic of early chilhood. (2) Islam has explained the rights and protection of children (3) understanding the characteristic of the children is one of the core of anti-violence education against children.
\end{abstract}

Keywords Education, Violence, Child, Islam.

\begin{abstract}
A bstrak Artikel ini bertujuan untuk menganalisis pendidikan anti kekerasan terhadap anak usia dini dalam perspektif Islam. Metode pengumpulan data yang digunakan ialah studi dokumentasi. Teknik analisis data yang digunakan ialah analisis kritis. Berdasarkan metode tersebut, diperoleh temuan penelitian bahwa: (1) kekerasan terhadap anak terjadi akibat rendahnya pemahaman tentang anak sejak usia dini. (2) Islam telah menjelaskan hak dan perlindungan terhadap anak (3) pemahaman mengenai kondisi anak merupakan salah satu inti pendidikan anti kekerasan teradap anak.
\end{abstract}

Kata kunci: Pendidikan, Kekerasan, Anak, Islam.

\section{Pendahuluan}

Kekerasan terhadap anak merupakan kasus yang sering terjadi akhir-akhir ini. Kekerasan merupakan salah satu bentuk tindakan tidak terpuji dan dilarang agama. Padahal negara sudah mengatur hal tersebut dalam UU no. 23 Tahun 2003 tentang Perlindungan anak, Pasal 4 yang berbunyi "Setiap anak berhak untuk dapat hidup, tumbuh, berkembang dan berpartisipasi secara wajar sesuai dengan harkat dan martabat kemanusiaan, serta mendapatkan perlindungan dari kekerasan dan diskriminasi".

Komisi Perlindungan Anak Indonesia (KPAI) menyatakan, kekerasan pada anak selalu meningkat setiap tahun. Terdapat lima kasus tertinggi pada tahun 2011-2015 yaitu: anak berhadapan dengan hukum tercatat 6006 kasus, pengasuhan 3160 kasus, pendidikan 1764 kasus, kesehatan dan napza 1366 kasus, serta pornografi dan cybercrime 1032 kasus. H asil monitoring dan evaluasi KPAI tahun 2012 di 9 provinsi menunjukkan bahwa 91 persen anak menjadi korban kekerasan di lingkungan keluarga, 87.6 persen di lingkungan sekolah dan 17.9 persen di lingkungan masyarakat. 
Indonesia merupakan negara yang mayoritas berpenduduk muslim. Islam sangat menjungjung tinggi dan mengajarkan kasih sayang. Sungguh ironis ketika kasus kekerasan anak terjadi di Indonesia. Kekerasan anak yang dilkukan oleh orang tua merupakan tindakan yang tidak mendidik dan menjadi contoh yang tidak baik untuk anak.

A lasan terjadinya kekerasan tersebut beragam, diantaranya disebabkan oleh kenakalan anak yang membuat orang tuanya marah dan berakhir dengan kekerasan fisik kepada anak. A kibat dari tindakan tersebut terdapat luka fisik maupun psikis kapada sang anak. A kibat lainnya dapat mempengaruhi rasa percaya diri anak yang akhirnya berakibat pada kondisi sosial dan prestasi anak.

Dampak yang paling parah adalah ketika akhirnya anak meniru kekerasan yang dialaminya dan bertingkah laku agresif terhadap orang lain. Bahkan yang terburuk ketika sikap tersebut akhirnya diturunkan kembali kepada generasi selanjutnya.

Padahal seharusnya, keluarga merupakan tempat pertama dan yang paling utama bagi anak dalam pembentukan mental dan kepribadian. Hal tersebut selanjutnya disempurnakan di sekolah dan di lingkungan sosial tempat anak tumbuh dan berkembang (Alex, 1991: 19). Hal ini sesuai dengan hadist nabi yang menyatakan bahwa "setiap anak dilahirkan dengan fitrah. Maka ayahnyalah (lingkungan) yang akan menjadikannya Yahudi, Nasrani, Majusi” (H.R. Muslim). Maka, pendidikan Islampun seharusnya dikenalkan dan ditanamkan kepada anak sedini mungkin.

Kekerasan terhadap anak dalam pandangan Islam merupakan bentuk pelanggaran amanah. Islam memandang anak sebagai amanah yang Allah titipkan kepada orang tua. Semua orang tua berkewajiban untuk mendidik anaknya agar menjadi soleh dan solehah, berilmu dan bertaqwa (Rose, 2003: 24).

Peran keluarga sangatlah signifikan terhadap perkembangan anak. M aka orang tua sudah seharusnya aktif dalam mengawal perkembangan moral dan intelektual anak. Dengan demikian generasi penerus akan memiliki sikap dan mental yang lebih matang.

$\mathrm{N}$ amun realitas berbeda dengan apa yang diinginkan. Kurangnya pendidikan agama yang dimiliki orang tua, ditambah dengan keadaan sosial lainnya yang terjadi membuat para orang tua memiliki tekanan hidup yang tinggi. $\mathrm{H}$ al tersebut akhirnya berdampak kepada keadaan dalam berkeluarga. Salah satunya berimbas kepada anak.

Maka, dengan pendidikan Islam diharapkan dapat mengurangi dampak sosial yang ada sehingga akhirnya keluarga dapat bersikap positif atas keadaan yang ada yang akhirnya mengurangi dampak tekanan hidup yang berimbas kepada kekerasan dalam keluarga, terkhusus kepada anak. Pendidikan Agama Islam adalah pendidikan melalui ajaran-ajaran agama Islam, yaitu usaha berupa bimbingan dan asuhan terhadap anak didik agar ia dapat memahami, menghayati dan mengamalkan ajaran-ajaran agama Islam serta menjadikannya sebagai pandangan hidup (Zakiah, 2000: 86).

Pendidikan agama Islam merupakan salah satu pendidikan yang mengajarkan anti kekerasan kepada anak. Dengan memahami pendidikan anti kekerasan dan pemahaman anak 
usia dini, diharapkan dapat menjadi salah satu jalan dalam menanggulani kasus kekerasan terhadap anak.

Berdasarkan permasalahan di atas, maka tujuan penelitian ini, ialah untuk mengetahui (1) kosep anak dalam perspektif Islam, (2) menganalisis konsep kekerasan terhadap anak dalam perspektif Islam, dan (3) mengeksplorasi konsep pendidikan anti kekerasan terhadap anak dalam perspektif Islam.

\section{Konsep Anak}

Dalam Undang-Undang Republik Indonesia Nomor 23 tahun 2003 tentang perlindungan anak pasal 1 ayat 1 diartikan "Anak adalah seseorang yang belum berusia 18 (delapan belas) tahun, termasuk anak yang masih dalam kandungan".

Seorang anak akan menjadi karunia atau nikmat jika orang tua berhasil mendidiknya menjadi anak yang baik dan berbakti. Namun jika sebaliknya, maka hal tersebut menjadi malapetaka bagi orang tuanya. A da empat tipologi anak dalam al-Quran:

1. Anak sebagai perhiasan hidup di dunia. Anak adalah perhiasan dalam rumah tangga. alQuran menyebutkan: "Harta dan anak-anak adalah perhiasan kehidupan dunia, namun amal yang kekal dan shalih adalah lebih baik pahalanya di sisi Tuhanmu serta lebih baik untuk menjadi harapan" (Q.S. AI-Kahfi: 46). A yat tersebut, menerangkan, bahwa anak berfungsi sebagai perhiasan dalam keluarga. Kesempurnaan dan keindahan rumah tangga akan lebih terasa ketika sudah terdapat anak di dalamnya;

2. Anak sebagai penyejuk hati. Selanjutnya, al-Quran menyebutkan bahwa anak adalah penyejuk mata atau hati. $\mathrm{H}$ al tersebut terjadi karena disaat mata memandang anak akan timbul rasa bahagia. "Ya Tuhan kami, anugerahi kepada kami pasangan kami dan keturunan kami sebagai penyejuk hati dan jadikanlah kami pemimpin bagi orang-orang yang bertakwa" (Q.S AI-Furqan: 74). Dari ayat tersebut, Allah mensyari'atkan kepada kita untuk berdo'a agar mendapatkan anak yang akan menadi penyejuk hati;

3. Anak sebagai Ujian. Anak juga dapat menjadi ujian bagi orang tuanya. Anak merupakan ujian apakah ia akan menunjukkan jalan surga atau neraka. Jika anak tersebut menjadi anak yang shaleh dan berbakti kepada orang tua, maka orang tuanya lulus ujian. Namun, jika karena anaknya orang tua lalai dari mengingat Allah, maka ia gagal dalam ujiannya. Anak sebagai ujian ini dijelaskan dalam al-Quran "Ketahuilah, hartamu dan anak-anakmu itu hanyalah ujian (Q.S AI-Anfal: 28). Dalam ayat yang lainnya "Hai orang-orang beriman, janganlah hartamu dan anak-anakmu melalaikan kamu dari mengingat Allah. Barangsiapa yang berbuat demikian Maka mereka Itulah orang-orang yang merugi”. (Q.S AIM unaafiquun: 9).

4. A nak sebagai musuh orang tua. Anak juga dapat menjadi musuh orang tua, jika sang anak tidak taat terhadap orang tuanya atau agamanya. Seperti anak yang murtad, berbuat kejahatan dan menimbulkan penderitaan bagi orang tuanya. Pada kasus tersebut sang anak sudah menjadi sahabat bagi setan dan musuh bagi orang tua. Jika orang tua salah dalam 
mendidik anaknya, maka anak tersebut bisa menjadi musuh bagi orang tuannya. $\mathrm{Hal}$ tersebut termaktub dalam AI-Qur'an "Hai orang-orang yang beriman, sesungguhnya di antara istri-istrimu dan anak-anakmu adalah musuh bagimu, maka berhati-hatilah kamu terhadap mereka"Q.S At-Thagabun: 14).

Islam juga menegaskan bahwa anak terlahir suci tanpa memiliki kesalahan. Hal tersebut berdasar pada sabda Nabi "Setiap anak itu dilahirkan menurut fitrahnya, maka kedua orang tuanyalah yang akan menjadikannya seorang Yahudi, Nasrani atau Majusi" (H.R. Bukhari). A nak merupakan aset bagi orang tuanya di hari tua dan di akhirat kelak. Jika anak tumbuh dengan baik dan optimal maka orang tuanyalah yang akan menikmati hasilnya. Nabi saw bersabda "Sesungguhnya usaha yang paling baik untuk dinikmati adalah hasil jerih payah tangan sendiri dan seorang anak adalah merupakan usaha dari orang tuanya" (H.R. A hmad). Artinya, jika seorang anak berbuat kebaikan maka orang tuanya mendapatkan kebaikannya juga.

Anak juga memiki kebutuhan yang seharusnya dapat dipenuhi. H. Salihun. A. Nasir (Nasir, 199: 72) menggolongkannya menjadi empat golongan yaitu: kebutuhan biologis seperti haus, bernafas, mengantuk, dan lain-lain; kebutuhan psikis seperti agama, kesehatan jiwa dan rasa aman; kebutuhan sosial seperti bergaul, berkelompok, pengalaman dan penghargaan; dan kebutuhan kasih sayang.

\section{Kekerasan terhadap anak}

Kekerasan memiliki definisi yang beragam. Kekerasan dapat berarti penganiayaan, penyiksaan, atau perlakuan salah. Dengan demikian kekerasan adalah perilaku tidak layak yang mengakibatkan kerugian atau bahaya fisik, psikologis atau finansial, baik yang dialami individu atau kelompok (Abu, 2012: 44).

M enurut Komisi Perlindungan Anak Indonesia (KPAI), kekerasan didefinisikan sebagai segala bentuk tindakan terhadap anak yang berakibat timbulnya penderitaan secara fisik, mental, seksual, psikis, emosional dan penelantaran termasuk pemaksaan dan merendahkan martabat.

Kekerasan terhadap anak merupakan perbuatan semena-mena orang yang seharusnya pelindung pada seorang anak secara fisik, seksual dan emosional (Abu, 2012:42). Perilaku kekerasan terhadap anak sangat tidak sesuai dengan martabat kemanusiaan maupun hak-hak korban yang melekat sejak lahir. Isu kekerasan terhadap anak tidak hanya merupakan masalah global, karena terkait dengan isu global tentang Hak A sasi M anusia (HAM) (M uladi, 2002: 60).

Bentuk kekerasan terhadap anak dapat diklasifikasikan menjadi empat macam yaitu: kekerasan secara fisik, kekerasan secara emosi, kekerasan secara seksual dan kekerasan secara verbal. Kekerasan fisik dapat berupa pemukulan, menendang atau menampar anak. Kekerasan psikologis dapat berupa memarahi atau membentak secara berlebihan serta mengeluarkan katakata yang tidak patut didengar anak. Sementara kekerasan seksual dapat berupa pemerkosaan, pencabulan, dan lainnya. 
Kekerasan fisik didefinisikan sebagai seluruh tingkah laku yang dapat mengakibatkan trauma dan luka fisik (Fields, 2002: 10). Contoh dari kekerasan fisik seperti memukul, menendang, menjambak rambut, mencekik, dan penggunaan alat dengan sengaja. Kekerasan seksual terhadap anak dapat diartikan seperti perlakuan tidak baik terhadap seksualitas anak. Contohnya menyentuh anggota tubuh pribadi untuk menyalurkan hasrat, melakukan masturbasi atau berhubungan seksual di depan anak, dan menggunakan anak dalam pornografi atau prostitusi. Sementara kekerasan psikis merupakan perlakuan orang dewasa yang membuat kondisi jiwa anak dalam keadaan tertekan. Hal tersebut terjadi jika orang tua berbicara terlalu keras, dan menggunakan kata-kata yang tidak pada tempatnya (H eman, 2006: 4).

Islam juga menyinggung beberapa contoh kekerasan terhadap anak. Kekerasan sangat tidak disukai dalam Islam. Beberapa contoh kekerasan dalam Islam diantaranya: M embunuh anak seperti dijelaskan dalam al-Quran "Janganlah kamu membunuh anak-anakmu lantaran takut kelaparan, kamilah yang akan memberikan rezeki kepada mereka maupun kamu, sesungguhnya membunuh mereka merupakan suatu dosa yang besar" (Q.S AI-Isra: 31) dan dalam surat lain "Dan apabila diperiksa anak perempuan yang ditanam hidup-hidup. Sebab dosa apakah dia dibunuh?" (Q.S At-Takwir: 8-9), perbedaan pemberian atau hak "Berlaku adillah kamu terhadap anak-anakmu. 'tiga kali'." (H.R A hmad, Nasai dan Abu Daud).

Terdapat banyak faktor yang melandasi terjadinya kekerasan terhadap anak, hal tersebut di antaranya anak yang polos atau tidak berdaya, rendahnya moralitas dan mentalitas pelaku, anak yang mengalami cacat tubuh atau gangguan tingkah laku, kemiskinan, serta lingkungan yang tidak baik.

Kekerasan anak akan berdampak terhadap banyak hal. Kekerasan pada anak akan menimbulkan dampak berupa psikis maupun fisik bagi anak. Jika anak terlalu sering mendapatkan kekerasan, perkembangan fisiknya akan terganggu. Secara psikologis anak akan menyimpan dan menanggung semua penderitaannya (Kartini, 1992: 8).

Selanjutnya anak akan mengalami penyimpangan kepribadian. Contohnya menjadi pendiam atau malah agresif, menyalahkan diri sendiri, mudah curiga, tertutup, mudah marah, malu, depresi, panik. Hingga yang lebih memprihatinkan ketika anak meyakini kekerasan sebagai salah satu cara yang dapat diterima dalam menyelesaikan suatu masalah.

\section{Pendidikan anti kekerasan anak}

Pendidikan anak adalah perkara yang penting dalam agama Islam. Sebagaimana Allah menceritakan Luqman mengajari anaknya dalam al-Quran. Begitupun dalam Hadis Rasulullah SA W yang mencontohkan pendidikan terhadap anak, baik melalui perintah maupun perbuatan langsung.

Pendidikan anti kekerasan anak juga didapatkan ketika orang tua memahami tugas-tugas perkembangan anak. Robert Havighurts menjelaskan bahwa tugas-tugas perkembangan pada anak bersumber pada tiga hal, yaitu: kematangan fisik, rangsangan atau tuntutan dari masyarakat dan norma pribadi mengenai aspirasi-aspirasinya. Tugas perkembangan anak usia 
0-6 tahun, meliputi belajar mengfusikan visual motoriknya secara sederhana, belajar bahasa, kontrol badan, mengenali realita sosial atau fisiknya, terlibat secara emosional dengan orang tua, membedakan yang benar dan salah serta membentuk nurani. Sementara tugas perkembangan anak usia 6-12 tahun adalah menggunakan kemampuan fisiknya, belajar sosial membaca, menulis, menghitung, kebebasan pribadi, bergaul, mengembangkan moral dan mengembangkan sikap terhadap kelompok sosial atau lembaga (Zahrotun, 2006: 56).

Pada periode anak-anak akhir ada tiga proses perkembangan, yaitu: perkembangan kognitif, psikososial, dan moral. Perkembangan kognitif dapat dilihat dengan anak yang sudah mampu berpikir operasional, menggunakan konsep matematis, dan mampu mengklasifikasi. Perkembangan psikosoial merupakan perkembangan produktifitas dan inferioritas. Sementara perkembangan moral ditandai dengan anak berorientasi pada individualisme dan tujuan. Pemikiran moral anak akan didasarkan pada reward dan minat pribadi (Zahrotun, 2006: 130).

Seharusnya orang tua menjadi teladan dan pengajar pertama dan utama bagi anaknya. Beberapa hal yang penting untuk diajarkan dan dapat menjauhkan dari kekerasan adalah: ketauhidan, Agama, akhlak, kejujuran dan keadilan, menjadi teladan yang baik, serta memberikan perhatian terhadap anak.

Selain itu, memahami hak anak terhadap orang tua juga menjadi bagian dari pendidikan anti kekerasan terhadap anak. A dapun hak-hak tersebut di antaranya:

1. Hak untuk hidup. Hak yang paling mendasar bagi manusia adalah hak untuk hidup. Inilah sebabnya mengapa seseorang tidak boleh membunuh orang lain (Hamid, t.th: 139). AlQuran menyebutkan "Maka barang siapa yang membunuh satu manusia tanpa kesalahan, maka ia seperti membunuh manusia seluruhnya dan barang siapa yang menghidupkannya, maka ia seperti menghidupkan seluruh manusia" (Q.S AI-M aidah: 32). Secara tegas Islam melarang pembunuhan kepada anak-anak sebagaimana Q.S AI-Isra yang telah dijelaskan sebelumnya. Dari kedua ayat tersebut dapat disimpulkan bahwa anak memiliki hak untuk hidup. Maka kekerasan terhadap anak sampai menyebabkan kematian tidak dibenarkan dalam Islam.

2. Hak untuk mendapatkan nasab yang jelas. Kejelasan nasab ini berguna untuk menentukan status anak agar mendapatkan hak dari orang tuanya. Sehingga anak dapat berinteraksi dan diterima di lingkungannya dengan wajar. Allah Berfirman dalam al-Quran "Panggillah mereka (anak-anak angkat itu) dengan (memakai) nama bapak-bapak mereka. Itulah yang lebih adil di sisi Allah. Dan jika kamu tidak mengetahui bapak-bapak mereka, maka (panggillah mereka sebagai) saudara-saudara seagama dan maula-maulamu” (Q.S AIAhzab: 5).

3. Hak mendapatkan nama yang baik. Memberikan nama merupakan kewajiban orang tua. Nama merupakan do'a dan harapan orang tua terhadap anaknya. Nama yang kurang baik biasanya akan mendapatkan interaksi yang tidak wajar dari lingkungannya yang berakibat kepada kekerasan psikis. Nabi saw bersabda "Sesungguhnya engkau akan dipanggil di hari kiamat kelak dengan nama-nama kamu dan nama-nama bapak kamu, maka baguskanlah nama-nama kamu" (H.R. Abu Daud). 
4. Hak memperoleh ASI (air susu ibu). Islam mengajarkan orang tua untuk memberikan ASI kepada anaknya maksimal selama dua tahun. Sebagaimana firman Allah "Para ibu hendaklah menyusukan anak-anaknya selama dua tahun penuh, yaitu bagi yang ingin menyempuranakan penyusuan" (Q.S AI-Baqarah: 233). Secara teoritis, pemberian ASI akan memenuhi kebutuhan gizi anak serta anak akan meradakan kasih sayang, kelembutan dan perhatian dari orang tuanya.

5. Hak mendapatkan asuhan, perawatan dan pemeliharaan. Setiap anak memiliki hak untuk mendapatkan asuhan, perawatan dan pemeliharaan hingga mereka dewasa. Pembentukan jiwa anak akan sangat dipengaruhi oleh cara perawatan dan pemeliharaan anak dari sejak lahir. Allah SWT. bersabda "Hai orang-orang yang beriman, periharalah dirimu dan keluargamu dari api neraka yang bahan bakarnya adalah manusia dan batu" (Q.S. AtTahrim:6). Ali Bin abi Thalib mengatakan bahwa yang dimaksud menjaga dari api neraka adalah dengan mengajari dan mendidik mereka (Ghufran, 2007: 70). Dengan demikian mengajari dan mendidik anak adalah kewajiban orang tua.

6. Hak dalam kepemilikan harta benda. Islam menetapkan anak yang baru lahir telah menerima hak waris. Nabi SAW bersabda "Bayi tidak boleh mewarisi sebelum lahir dengan mengeluarkan secara keras, yaitu menjerit, menangis atau bersin" (H.R. At-Tabrani). Ketujuh, hak mendapatkan pendidikan dan pengajaran. Nabi saw bersabda "Tidak ada suatu pemberian yang paling baik dari orang tua pada anaknya kecuali pendidikan yang baik". Ali bin A bi thalib berkata "Didiklah anak kalian dengan benar (serius) karena mereka dilahirkan bukan pada zaman kalian".

Selain adanya hak terhadap anak, Islam juga mengatur perlindungan terhadap anak. Hal ini dapat pula dicermati sebagai salah satu penguat pendidikan anti kekerasan. $\mathrm{Hal}$ tersebut di antaranya:

1. Perlindungan terhadap anak walaupun hasil zina. Hal ini sebagaimana sabda Nabi saw "Tidaklah termasuk golongan kami yang tidak menyayangi kaum muda dan tidak menghormati kaum tua" (H.R. Tirmidzi). Selain itu dalam kasus lain, ketika ada kasus wanita Bani Al-Ghamidiyah yang memberikan pengakuan bahwa dirinya hamil dari hasil berzina dan meminta hukuman, Rasul menyuruhnya untuk melahirkan, menyusui dan memberikan anak tersebut untuk diurus oleh keluarga muslim (H.R. M uslim). Walaupun anak tersebut lahir karena dosa sang ibu, bukan berarti anak tersebut ikut menanggung dosa akan tetapi harus disayangi dan dilindungi sebab setiap anak lahir tanpa membawa dosa.

2. Perlakuan adil dalam pemberian. Allah sangat sering memerintahkan umat manusia untuk adil sebagaimana Firman Allah dalam Q.S AI-M aidah ayat 8, Q.S An-Nisa ayat 127, dan yang lainnya. Begitu juga dengan apa yang diperintahkan oleh Nabi Muhammad saw. Rasulullah saw bersabda "Samakanlah di antara anak-anak kalian dalam pembarian" (H.R. At-Thabrani).

3. M enjaga nama baik. Nabi saw mengajarkan kita untuk menjaga nama baik terhadap anak kecil sekalipun. Imam Ghazali sangat mencela orang tua yang menghardik atau 
merendahkan anak. Hal tersebut hanya akan berdampak kepada perkembangan kepribadiannya yang menjadi bodoh atau lemah (AI-Ghazali, 1992: 178).

4. Melindungi anak dari perlakuan buruk. Nabi SAW bersabda "Seseorang itu mengikuti agama teman dekatnya. Oleh sebab itu, hendaklah seseorang memperhatikan siapa yang menjadi teman dekatnya" (H.R. A bu Daud). Kelima, melindungi anak dari kekerasan. Islam sangat mencela kekerasan terlebih kepada anak-anak. Maka, sudah seharusnya orang tua menjadi pelindung bagi anak-anaknya bukan malah menjadi pelaku dari kekerasan.

5. M elindungi anak dari kejahatan makhluk halus, Ibn A bbas menceritakan, bahwa $\mathrm{N}$ abi saw selalu membacakan ta'awudz (bacaan permohonan perlindungan) untuk al-Hasan dan alH usain. Ketujuh, menjaga anak dari penelantaran. Allah berfirman "... dan kewajiban ayah menanggung nafkah dan pakaian mereka dengan cara yang patut” (Q.S AI-Baqarah: 233). $\mathrm{Hal}$ ini juga seharusnya dapat menyadarkan bahwa eksploitasi terhdap anak tidak dibenarkan bagaimanapun keadaannya.

\section{Simpulan}

A nak merupakan amanah yang diberikan oleh Allah SWT. Anak merupakan calon generasi penerus karenanya anak harus diarahkan kepada perkembangan yang baik. AI-Quran menjelaskan bahwa anak dapat menjadi empat peran yaitu: sebagai perhiasan hidup di dunia, sebagai penyejuk hati, sebagai ujian dan sebagai musuh orang tua. Anak yang dididik dengan baik akan membawa manfaat dan membuka pintu surga untuk orang tuanya. Sebaliknya, kegagalan dalam mendidik anak hanya akan menjadikan anak sebagai musuh orang tuanya.

Kekerasan merupakan hal yang dibenci dalam Islam, apalagi jika yang menjadi korban adalah anak-anak usia dini. Kekerasan terhadap anak dapat berupa kekerasan secara fisik, seksual dan emosional. Terdapat banyak faktor yang melandasi terjadinya kekerasan terhadap anak, hal tersebut diantaranya anak yang polos atau tidak berdaya, rendahnya moralitas dan mentalitas pelaku, anak yang mengalami cacat tubuh atau gangguan tingkah laku, kemiskinan, serta lingkungan yang tidak baik.

Pendidikan anti kekerasan terhadap anak usia dini dapat berupa pemahaman orang tua tentang bagai mana seharusnya memperlakukan anak dari sedini mungkin. I slam telah mengatur hal-hal tersebut baik dalam hak anak maupun perlindungan terhadap anak. Hak anak yang seharusnya diberikan adalah: hak hidup, mengetahui nasabnya, mendapat nama yang baik, mendapatkan ASI, mendapatkan perawatan, waris dan pendidikan. Selain itu Islam juga mengatur perlindungan anak berupa: perlindungan anak, perlakuan adil, perlindungan nama baik, perlindungan dari perlakuan buruk, kekerasan, dan gangguan makhluk halus serta penelantaran. 


\section{Referensi}

Darajat, Zakiah., dkk. 2000. Ilmu Pendidikan Islam. Jakarta: PT. Bumi A ksara.

Fields, Tim. 2002. Issues Related to Bullying: Abuse. www.Successunling.co.uk/related/ abuse.htm\#abuse.

Ghufran, Ali. 2007. Lahirlah dengan Cinta: Fikih Hamil dan M enyususi. Jakarta: Amzah.

Heman. 2006. Kekerasan pada Anak-anak Indonesia. www.smeru.or.id

Hamid, Sholahuddin. (t.th). Hak A sasi M anusia dalam Perspektif Islam. Jakarta: A misco.

H amid Al-Ghazali, A bu. 1992. Ihya Ulum Ad-Din. Semarang: Asy-Syifa.

Huraerah, A bu. 2012. Kekerasan Terhadap Anak. Bandng: Nuansa Cendikia.

Kartini, Kartono. 1992. Patologi Sosial II: Kenakalan Remaja. CV. Jakarta: Rajawali.

Mini, Rose dan A. Priyanto. 2003. Perilaku Anak Usia Dini Kasus dan Pemecahannya. Yogyakarta: Kansius.

Muladi. 2002. Demokratisasi Hak Asai M anusia dan Reformasi Hukum di Indonesia Jakarta: The Habibie Center.

Nasir, Salman. 1999. Peranan Pendidikan Agama terhadap Pemecahan Problema Remaja. Jakarta: Kalam Mulia

Sobur, Alex. 1991. A nak M asa Depan. Bandung: Angkasa.

Zahrotun, dkk. 2006. Psikologi Perkembangan: Tinjauan Psikologi Barat dan Psikologi IslaM. Jakarta: UIN Jakarta Press. 
